\title{
ULTRASTRUCTURAL CHANGES OF ORGANELLES IN ROOT CAP CELLS OF TOBACCO UNDER SALINITY
}

\author{
Ekaterina N. Baranova ${ }^{1 \#}$, Inna A. Chaban ${ }^{1}$, Neonila V. Kononenko ${ }^{1}$, \\ Alexander A. Gulevich ${ }^{1}$, Ludmila V. Kurenina', and Elena A. Smirnova ${ }^{1,2}$ \\ 1 All-Russian Scientific Research Institute of Agricultural Biotechnology, 42 Timiryazevskaya Str., Moscow, RUSSIA \\ 2 Department of Cell Biology and Histology of the Biological Faculty of M. V. Lomonosov Moscow State University, Moscow, RUSSIA \\ \# Corresponding author, greenpro2007@rambler.ru
}

Communicated by Isaak Rashal

\begin{abstract}
We investigated how an abiotic factor, i.e. salinity, affects specific intracellular organelles of cells of the root cap. We focused on: 1) amyloplasts, which are specific plastids of the cap that perform important metabolic and sensory functions; and 2) mitochondria, which protect cells from ROS damage by changing their ultrastructure. In our work we studied the ultrastructural changes of these organelles in different areas of the root cap under $\mathrm{NaCl}$ and $\mathrm{Na}_{2} \mathrm{SO}_{4}$ impact. We showed that the amyloplasts (statoliths) and mitochondria of the columella and the peripheral zone of the cap change their structural organisation in the presence of $\mathrm{NaCl}$. Under action of $\mathrm{Na}_{2} \mathrm{SO}_{4}$, in plastids of columella the number of starch grains decreases dramatically, the cells of the peripheral part of the cap do not contain the amyloplasts, and the proplastids that do not store or store a little starch grains, which is attributed to leucoplasts with typical lamellae characteristic for root cortex cells. Thus, $\mathrm{Na}_{2} \mathrm{SO}_{4}$ influence has the most significant effect on the plastids of the root cap, and plastids of the cells of the peripheral zone of the cap are subjected to the most significant changes under salinity stress.
\end{abstract}

Key words: columella, salinity, amyloplasts, statoliths, starch grains, mitochondria, Nicotiana tabacum $L$.

\section{INTRODUCTION}

The root cap is located in the apical part of the root of most species of higher plants and performs a number of important functions, such as protection against mechanical damage when penetrating the root into the soil, carrying out various tropic functions (gravitropism, hydrotropism, etc.), and production of specific cells and mucilage that create favourable conditions for the existence of plant growth-promoting bacteria in the zones of the rhizoplan and rhizosphere (Iijima et al., 2008; Dessaux et al., 2016). In many plants, the cells of the peripheral part of the root cap are exfoliated and turn into the border cells that perform protective functions. Thus, the functions of the root cap are provided by a balanced proliferation of proximal meristematic cells and a regulated detachment of distal mature cells (Kamiya et al., 2016).

The root cap consists of the columella zone occupying its central part and the peripheral zone of the cap, which extends to the cells of the apical meristem and the distal part of the root extension zone (Hetherington et al., 2016). Above the columella are situated the cell-initials of the root cap meristem. In dicotyledons like Nicotiana tabacum L., apart from the quiescent centre, three types of root initials are seen - one is responsible for the formation of the vascular cylinder, the second gives rise to both the cortex and endodermis, and the third initiates the epidermis and the cap. This type of structural organisation of a meristem is classified as "closed". The cell-initials of root cap generate the first tier of the columella, which is then sequentially differentiated into the second and third tiers. Thus, in columella, the cell layers contain developing, functioning and degenerating cells.

In roots with the "closed" type of organisation of the apical meristem, the peripheral cells of the cap are released as sheets or groups of dead border cells (border-like cells), which unlike true border cells, are not alive. It is known that in the peripheral layer of the cap the processes of pro- 
grammed cell death begin, which lead to the formation of the exfoliated dead cell layers (Hamamoto et al., 2006).

Under the influence of different abiotic stresses, various disturbances of the proliferation, growth and differentiation of the root cells (Ghosh and $\mathrm{Xu}, 2014$ ) have been observed, and therefore much attention is paid to studying the condition of meristematic tissues under stress conditions. In the cap, with the exception of the initials, columella and peripheral cells are represented by subpopulations of terminally differentiated cells (Hamamoto et al., 2006). Presently there is a lack of information on how the cells and organelles in the cells of columella and the peripheral layer of the cap respond to abiotic stress factors. The study of the structural and functional changes of these cells to different stress impacts can provide an answer to the question of how the cap performs its protective functions.

One of the damaging effects of salinity is oxidative stress, which results in a significant increase in reactive oxygen species (ROS) (Gill and Tuteja, 2010). However, the mechanism of damage and ultrastructural features of the organisation of cristae and form of mitochondria can differ significantly: increase in size and loss of cristae, and decrease in size and increase of density with pronounced rhomboid cristae, often filled with electron-dense material, probably remnants of mitochondrial matrix (Čiamporová and Mistrík, 1993). Salt stress under light conditions causes changes in the following order in sweet potato cells: vacuolation, development and partial swelling of ER; decrease in mitochondrial cristae and swelling of mitochondria (Mitsuya et al., 2000). Recent results have identified mitochondria as centres of stress-induced generation of reactive oxygen species in plants. Previous work showed that depolarisation of the plant mitochondrial membrane during stress results in the release of programmed cell death (PCD)-inducing factors in the cytosol in a fashion similar to the onset of animal-like PCD. Herein, we report significant similarities of animal-like PCD and salinity stress-induced plant PCD. Short-term salinity stress $(3 \mathrm{~h})$ led to depolarisation of the mitochondrial membrane and release of cytochrome c (CYT-c) (Andronis and Roubelakis-Angelakis, 2010). In studying photosynthetic tissues, we observed a significant change in leaf mesophyll mitochondria when plants were cultivated in the presence of salts, which had features characteristic of $\mathrm{NaCl}$ and $\mathrm{Na}_{2} \mathrm{SO}_{4}$ isosmotic concentrations. Since the osmotic pressure of the solutions did not differ, it could be assumed that the toxicity of the ions of these salts is different (Baranova et al., 2007). This question is important because natural salinity is rarely accompanied by chloride salinization used commonly in scientific experimental practices, but often includes sulphate, sodicity, etc., including mixed types (Bresler et al., 2012).

Structural features of columella cells (statocytes) are: their structural polarisation, the presence of specialised plastids (amyloplasts) with starch inclusions, which perform the functions of statoliths, the non-canonical organisation of the ER system (Zheng and Staehelin, 2001). We have previously observed (Lazareva, 2011) that salts cause a signifi- cant disruption of the morphology of the root, which acquire bends or have a spiral shape. This influence can be associated with gravitropic effects (Hodson and Mayer, 1987) and therefore the study of starch-containing plastids (statoliths) at the root tip was the subject of our study.

Amyloplasts, other plastids and mitochondria have specialized important metabolic, synthetic, and sensory functions. In our work we studied the structural changes of these organelles in different zones of the cap when exposed to isosmotic concentrations of $\mathrm{NaCl}$ and $\mathrm{Na}_{2} \mathrm{SO}_{4}$ salts.

We determined differences in starch distribution between plastids of different zones and cell types of the root cap. This cytological approach showed notable structural changes in plastid structure during prolonged salt treatment. Our results are important for future biochemical and physiological analysis and assessment of accumulation of storage compounds in cells of different plant organs and tissues.

\section{MATERIALS AND METHODS}

Object of study. Tobacco plants of Nicotiana tabacum L. of cv. Samsun were grown for seven days on paper bridges in vitro in test tubes on $1 / 2$ liquid Murashige-Skoog medium with isosmotic concentrations of $\mathrm{NaCl}(97.4 \mathrm{mM})$ or $\mathrm{Na}_{2} \mathrm{SO}_{4}(77.5 \mathrm{mM})$, which corresponded to $405.2 \mathrm{kPa}$ or 4 atm (Lazareva et al., 2017). Both solutions used had the same osmotic values, but different anions $\left(\mathrm{Cl}^{-}\right.$and $\left.\mathrm{SO}^{-}\right)$ and molarity of $\mathrm{Na}^{+}\left(\mathrm{Na}_{2} \mathrm{SO}_{4}\right.$ contains $\mathrm{Na}+1.6$ times more than $\mathrm{NaCl}$ ). The average light intensity was $50 \mathrm{~W} / \mathrm{m} 2$, the temperature is $25 \pm 2{ }^{\circ} \mathrm{C}$ and the humidity is $60-70 \%$.

Light and transmission electron microscopy. Root tips (0.5-0.7 mm long) were fixed for 24 hours at $+4{ }^{\circ} \mathrm{C}$ in $2 \%$ glutaraldehyde (firm) solution on $0.1 \mathrm{M}$ Na-phosphate buffer ( $\mathrm{pH} 7.2)$ with sucrose $(15 \mathrm{mg} / \mathrm{ml})$, and then two times rinsed with buffer. Postfixation of the material was carried out in a $1 \%$ aqueous solution of $\mathrm{OsO}_{4}$. Dehydration with ethyl alcohol and the embedding of the material in epoxy resin were carried out according to the standard procedure. The polymerisation was carried out in two stages (day $+34{ }^{\circ} \mathrm{C}$, day $+60{ }^{\circ} \mathrm{C}$ ). During fixation, 5-7 "random" fragments were selected in the same zone, in this case, the root tip. Experiments were done in three replications. For analysis, at least three "random" roots were selected, from which semi-thin sections were made. After reaching the middle (longitudinal section), cutting of the root was stopped, and the section was photographed. After contrasting, they were viewed under an electron microscope and sample images were taken from each sample. Further, for the analysis, photographs were taken of plastids and mitochondria in accordance with different zones (tissues) for visual analysis (with an magnification of 5000) and selecting images with characteristic plastids with an magnification of 8-17000 for high-quality images. Semi-thin $(1.5 \mu \mathrm{m})$ and ultra-thin $(500$ $\mu \mathrm{m})$ transverse sections of the root tips were obtained on the microtome LKB-V (Sweden) and placed respectively in a drop of resin on a slide or on copper blends coated with a 
form-blank film. Samples were analysed with an Olympus light microscope. Ultrathin sections were stained with uranyl acetate, then with lead citrate, and examined under a transmission electron microscope H-500 (Hitachi, Japan) at an accelerating voltage of $100 \mathrm{kV}$.

\section{RESULTS}

Structural organisation of the root cap. The root cap of the control tobacco plants had a typical structure for roots of dicotyledonous plants and consisted of initial cells, columella occupying its central part, and the peripheral zone of the cap, which surrounded the columella zone and bordered on the apical meristem, initials and differentiating cells of the epidermis (Fig. 1a). Above the columella were the meristematic cells of cap initials and epidermis (calyptrogen) (Fig. 1a, d). It is known that columella cells (statocytes) are formed from the calyptrogenic cells of the apical meristem. Statocytes are larger in size than meristem cells due to presence of a vacuole, and their plastids accumulate starch inclusions, significantly increasing the size of the plastid and the size of the cells (Fig. 1a). It is assumed that they have a polarised form (their nucleus is located in the upper half of the cell). Amyloplasts with starch granules (statoliths) are located in the lower part of the cells. This location is due to the fact that amyloplasts have a high density of $1.5 \mathrm{~g} / \mathrm{cm}^{3}$, while the surrounding cytoplasm has a density of about $1 \mathrm{~g} / \mathrm{cm}^{3}$ (Su et al., 2017). In tobacco columella consisted of three tiers of cells. The first cell tier (the smallest in columella) is derived from the initials, the cells of the second tier are larger and contain more vacuoles, and the third tier of cells (the largest) differentiates into the peripheral layer of the cap, which is represented by one or two layers of cells. The cells of the peripheral layer of the cap are highly vacuolated and have a smaller cytoplasm volume. The cytoplasmic density of these cells was significantly increased; their shape was elongated and flattened, in contrast to the rounded cells of the central zone of columella (Fig. $1 \mathrm{a}, \mathrm{d})$. It is possible that this might be due to the retention of the vacuolar volume under disturbance of water flow into the cytoplasm in relation to a change in the spatial connection of cells of the peripheral zone with the columella cells and the resulting loss of turgor leading to a change in the shape of the cells and the water content of the cytoplasm.

$\mathrm{NaCl}$ treatment caused a change in both the size of the cap and columella cells by a factor of 2 , and $1.2-1.5$, respectively, and in the peripheral zone by a factor of 2-2.5. These changes mainly affected the thickness of the cells, which was probably caused by a decrease in water supply or a decrease in the osmotic pressure of the solutions coming from the suction zone (Fig. 1b, d). In the cap cells there was a decrease in size and disturbance of the vacuole fusion, and a chaotic distribution of amyloplasts. The cytoplasm of columella cells was insignificantly different in appearance from the cytoplasm of the cells of the cap initials, which probably indicated a reduction in the rate of differentiation of the cap cells in the presence of $\mathrm{NaCl}$ (Fig. 1b, d). $\mathrm{Na}_{2} \mathrm{SO}_{4}$ increased the size of the cap is 1.3 times. The ob-
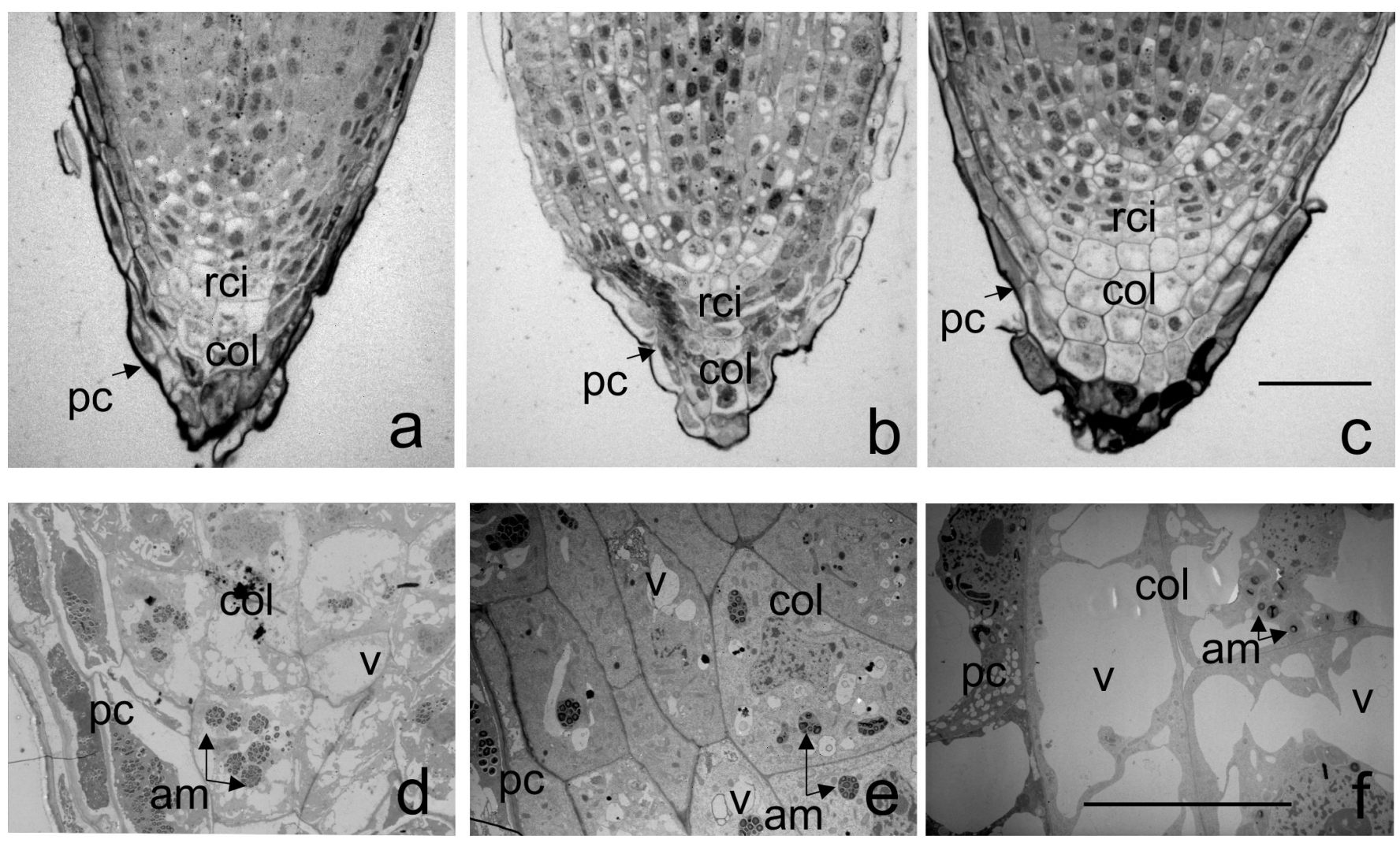

Fig. 1. Sections of the control plants roots of tobacco (a, d), under the influence of $\mathrm{NaCl}(\mathrm{b}, \mathrm{e})$, under the influence of Na2SO4 (c, f); a-c, semi-thin sections; $\mathrm{d}-\mathrm{f}$, ultrathin sections from the columella zone and the peripheral part of the root cap. Abbreviations used: rci, initiali, col, columella, pc, peripheral cells of the root cap. Scale bar $(\mathrm{a}-\mathrm{c})$ is $50 \mu \mathrm{m}$, scale bar $(\mathrm{d}-\mathrm{f})$ is $20 \mu \mathrm{m}$. 
served swelling of the statocytes was probably due to an increase in the volume of the vacuoles (by 1.5 times) and at the expense of cells of the peripheral layer of the cap (by 1.2 times) (Fig. 1c, e). Under the action of $\mathrm{NaCl}$, the cytoplasm was denser than in cells of cap of the control variant.

Ultrastructural organisation of plastids. Plastids in the cell-initials of meristem were heterogeneous in size and shape, and these organelles probably represented various transitional forms that were differentiated from proplastids characteristic for meristematic tissues. They had an inhomogeneous density, loosened stroma with light zones, which were probably zones of nucleoid location (Fig. 2a).
Under the action of $\mathrm{NaCl}$ and $\mathrm{Na}_{2} \mathrm{SO}_{4}$ a significant change in the ultrastructural organisation of plastids was observed, which can probably be characterised as different transition forms from the proplastide to the leucoplast (Fig. 2d, g). The stroma of plastids had a denser structure and the lighter zones were weakly pronounced, probably due to a reduction in nucleoid activity. There were single plastoglobules and starch inclusions in the stroma. In addition, lamellar structures of light colour and membrane formations having osmiophilic dark contents were observed in the stroma. In some cases, the relationships of these structures with dark osmiophilic inclusions characteristic of proteinoplasts are noted (Vigil and Ruddat, 1985). Plastids typical for colum-
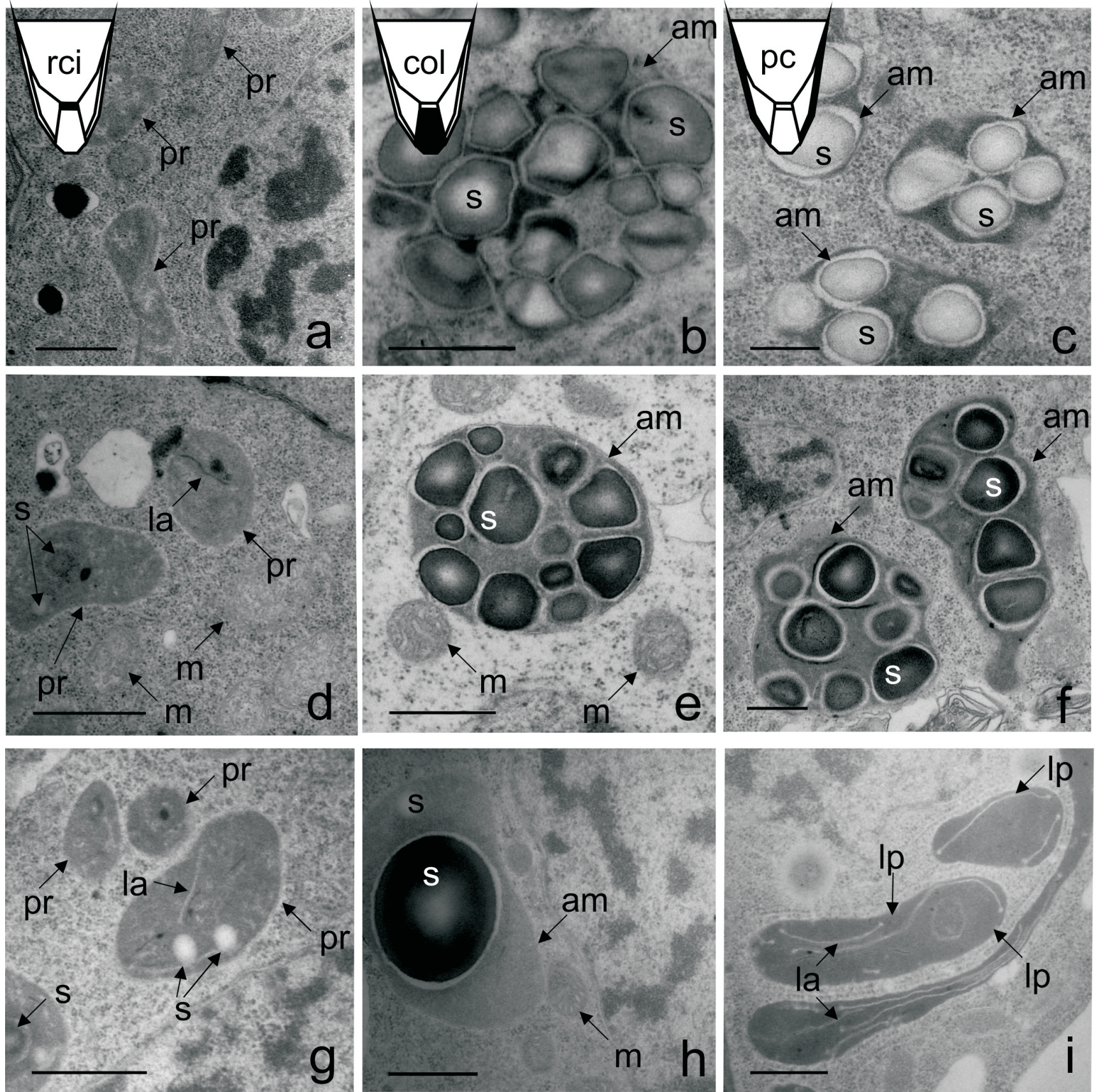

Fig. 2. Ultrastructural organization of plastids in the root cap of the roots of the control plants of tobacco (a-c), under the influence of $\mathrm{NaCl}(\mathrm{d}-\mathrm{f})$ and under the influence of Na2SO4 (g-i). a, d, g, plastids in cells from the root cap initial zone (rci); b, e, h, amyloplasts of statolith in columella cells (col); c, f, I, amyloplasts and plastids in the cells of the peripheral zone (pc) of the root cap. Abbreviations used: pr, proplastids; am, amyloplast; lp, leucoplast; la, lamella; $\mathrm{m}$, mitochondria, s, starch. Scale bar $=1 \mu \mathrm{m}$. 
ella statocytes in all stages of differentiation, amyloplasts performing the functions of statoliths, were present in control plants (Fig. 2b). The border of the amyloplast had an uneven edge, the outer membrane was fragmented, the starch granules were evenly distributed over the stroma, and the stroma contained amorphous osmiophilic contents unevenly distributed in the plastid volume. Statoliths in columella cells of the control plants were arranged in groups, probably related to a gravitropic function. It is believed that these structures differ from amyloplasts storing starch: in statocytes, starch granules (statoliths) have a boundary layer, which binds all the starch granules to a joint system inside the amyloplast (Staehelin et al., 2007).

Under the action of $\mathrm{NaCl}$ the amyloplasts (statoliths) are also present in columella cells of all stages of differentiation (Fig. 2e). The size of these plastids was somewhat less than the size of the statoliths in the columella cells of the control plants (approximately 1.2 times). The size of the starch granules did not differ from that in the control, and they were evenly distributed in the homogeneous granular stroma of the amyloplast. The plastid membrane was clearly identified in the sections.

Under the action of $\mathrm{Na}_{2} \mathrm{SO}_{4}$ amyloplasts in statocytes contained 1.5-2 times larger starch granules than in amyloplasts of control cells. In addition, the number of starch grains was much (more than 10 times) less (1-2 grains per section). Furthermore, such starch grains had a different electron density (Fig. 2h) and different nature or function.

According to some publications, the processes of programmed cell death are initiated in peripheral cells of the cap in plants with a closed organisation of the apical meristem (Hamamoto et al., 2006). In these cells the amyloplast statoliths are also fairly well pronounced (Fig. 2c). They lose their rounded shape, acquire an indefinite form, have a granular stroma, and have more clearly delineated outer membranes than in columella cells. Starch inclusions are characterised by smoother edges.

Under the action of $\mathrm{NaCl}$ in periferal cells of a cap, typical amyloplasts with an internal structure similar to amyloplast structure of columella cells under the same conditions, were observed. The plastid shape, as in the control, was irregular and had significant bends; the starch inclusions were characterised by a smoother surface (Fig. 2f), as in the control cells (Fig. 2c).

However, when plants were exposed to $\mathrm{Na}_{2} \mathrm{SO}_{4}$, the plastids from this outer boundary zone of the cap became similar to typical leucoplasts: dense stroma without lighter inclusions, with single or multiple light lamellae (Fig. 2i). The inclusions of starch and plastoglobules were single and small (not shown).

Ultratructural organisation of mitochondria. To determine the effect of $\mathrm{Na}^{+}, \mathrm{Cl}^{-}, \mathrm{SO}_{4}{ }^{2-}$ ions on the most important structural component of the eukaryotic cell, which ensures the energy stability of the processes of cellular metabolism, we studied the ultrastructural organisation of mitochondria in the areas of root cap initial cells (rci), columella (col) and peripheral cells (pc) (Fig. 3a-c). The use of iso-osmotic salt solutions allows to take into account the effect of $\mathrm{Cl}^{-}$and $\mathrm{SO}_{4}^{-}$anions in the experimental model (Lazareva et al., 2017). Structural organisation of mitochondria in the cells of the root cap showed clear differentiation depending on the tissue (Fig. 3). The mitochondria in the root cap initials of control plants had a typical structural organisation. The shape was round or oval, single cristae could be identified in the section, containing a mitochondial DNA light zone surrounded by loose matrix with a clear granular structure corresponding to typical prokaryotic ribosomes (smaller in comparison with ribosomes located in the cytoplasm) (Fig. 3a). $\mathrm{NaCl}$ treatment caused an increase in the number of cristae on the mitochondria sections of rci (more than ten times). In addition, the size of light areas of the matrix and the number of ribosomes were decreased (Fig. 3d). $\mathrm{Na}_{2} \mathrm{SO}_{4}$ treatment caused a decrease in the area of the cut by a factor of 1.5 , and hence, the reduction of mitochondrial volume. Formation of parallel located cristae was observed. The matrix occupied an insignificant volume of mitochondria, and was not well distinguishable in a number of sections (Fig. 3g). Mitochondria of columella cells of the control plants had a typical mitochondrial structure characteristic of dying cells. These organelles had uneven edges and invaginations of envelope. The large rhombus-like cristae of irregular shape filled the entire volume. The membranes were contrasting. A darkly coloured matrix retained the granular structure characterised by large amount of ribosomes (Fig. 3b). Under the $\mathrm{NaCl}$ treatment, the mitochondria in the columella cells retained a rounded or oval shape, were filled with a relatively loose matrix, had from 5 to 13 cristae per cut and a denser cell cytoplasm than in the control cells. This probably indicates a delay in the differentiation (aging) of the cells of this zone under $\mathrm{NaCl}$ exposure (Fig. 3e). $\mathrm{Na}_{2} \mathrm{SO}_{4}$ caused similar changes in mitochondria of columella cells. Their shape remained round. They contained groups of cristae and a more loosened matrix than under $\mathrm{NaCl}$ exposure. On a number of sections it was possible to identify light zones with clearly visible mitochondrial DNA (Fig. 3h).

Mitochondria of cells of the peripheral zone had a ultrastructure characteristic for dying cells of the cap and epidermis. The mitochondria located in the dense cell cytoplasm had a slightly curved edge of outer membrane, small rhombus-like cristae, and osmiophilic stroma with an amorphous structure in which small inclusions, presumably ribosomes, were dispersed. A number of mitochondria had large section areas, possibly indicating a reduction in fission or fusion processes characteristic for these organelles (Fig. 3c). The mitochondria of pc cells under the action of $\mathrm{NaCl}$ retained an oval form. They contained blocks of chaotically located flattened cristae. Matrix or fragments containing DNA were not visible in the organelles (Fig. 3f). $\mathrm{Na}_{2} \mathrm{SO}_{4}$ treatment resulted in a similar change in the structural organisation - the filling of the entire internal area with blocks of parallel cristae (Fig. 3i). 

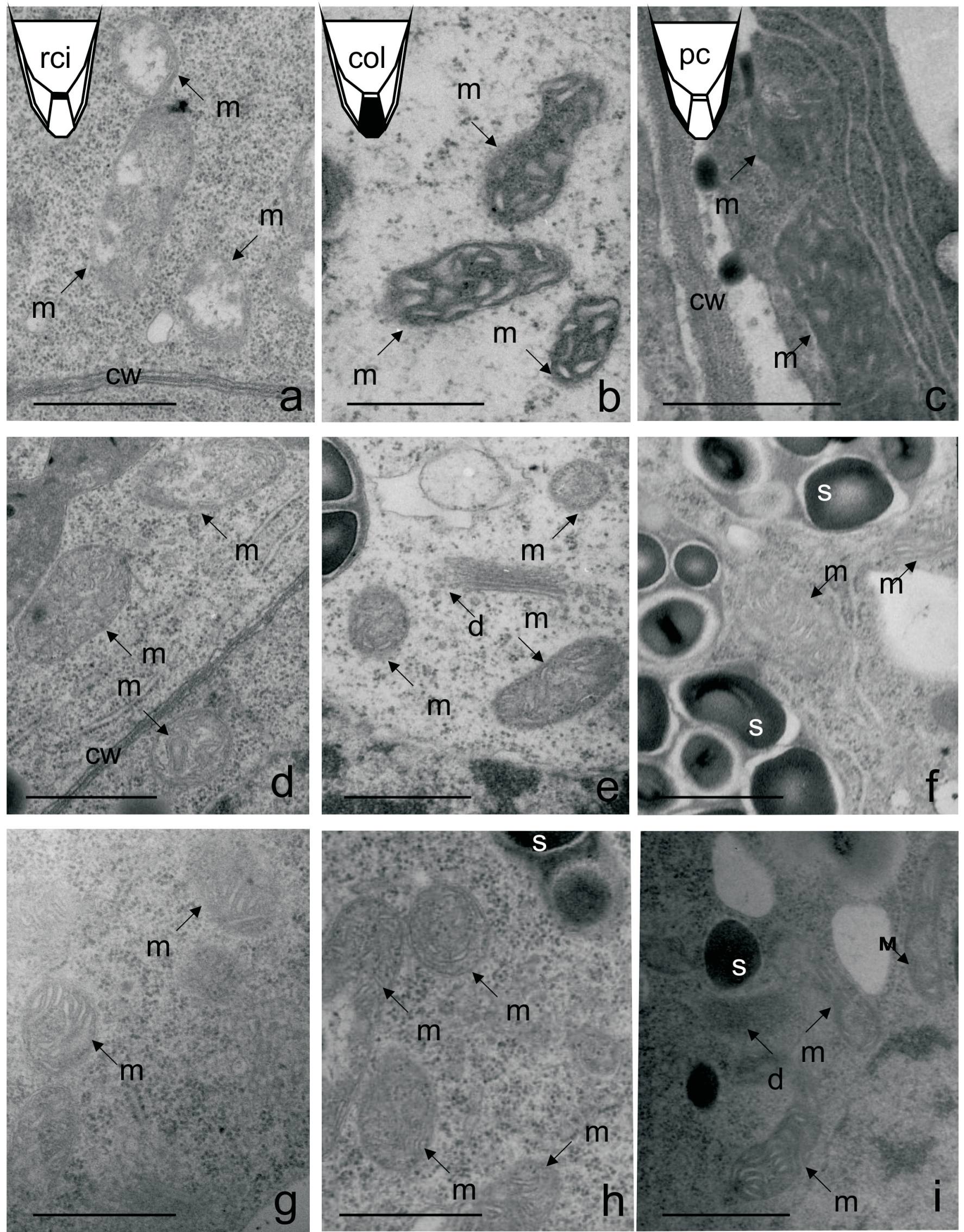

Fig. 3. Ultrastructural organisation of mitochondria in the root cap of the control plants of tobacco roots (a-c), under the influence of $\mathrm{NaCl}$ (d-f) and under the influence of $\mathrm{Na} 2 \mathrm{SO} 4$ (g-i). a, d, g, mitochondria in cells from the root cap initial zone (rci); b, e, h, mitochondria in columella cells (col); c, f, I, mitochondria in the cells of the peripheral zone (pc) of the root cap. Abbreviations used: $\mathrm{m}$, mitochondria, cw, cell walls; d, dyctiosome; s, starch grain. Scale bar $=800 \mathrm{~nm}$. 


\section{DISCUSSION}

Salinity has a number of known effects characteristic of most of abiotic osmotic and oxidative stresses due to the toxic effects of ions (Baranova et al., 2007). Earlier, we showed that the ultrastructural organisation of plastids and the quantity of storage reserves deposited in plastids are sensitive to the action of ions of the salts on alfalfa (Baranova et al., 2007), tobacco (Baranova et al., 2009) and tomato plants (Baranova et al., 2011). The sensitivity of the processes of polysaccharide metabolism, utilisation and formation of starch grains to abiotic stresses is confirmed by previous studies on the presence and structural organisation of the plastids of the photosynthetic part of plants - the leaf mesophyll leaf (Poljakoff-Mayber, 1975; Sam et al., 2003; Ahmed et al., 2013). At present, it is obvious that in addition to changes to the photosynthetic compartment of the leaf, it is necessary to investigate the localisation of starch in root cells. This makes it possible to determine damage to the long-distance transport of polysaccharides to the root and alterations in the processes of development of the root system and provision of mitochondria with energy for the production of ATP (Fanello et al., 2017; Thalmann and Santelia, 2017). Thus, in modern studies much attention is paid to controlling the presence and location of starch as the main reserve polysaccharide in plastids of various root tissues (Ibrahim et al., 2017, Acosta-Motos et al., 2017).

Our studies showed that the plastids of the cap initials, columella cells and the peripheral zone of the cap differ in response to $\mathrm{NaCl}$ and $\mathrm{Na}_{2} \mathrm{SO}_{4}$. In the cap initials the action of both salts was accompanied by the condensation of plastid stroma, and the appearance of lamellar structures and starch inclusions, which apparently have a storage function. Under $\mathrm{NaCl}$ treatment, amyloplasts in the cells of the columella and the peripheral zone of the cap did not change their structural organisation. This is consistent with results of a study on the effect of salinity $(0.15 \mathrm{M} \mathrm{NaCl})$ on the ultrastructure of cellular organelles (Usatov et al., 2014) in which plastids in the cells of the root of wheat were observed to be most sensitive and the degree of the detected changes depended on the concentration of salt.

However, under the effect of $\mathrm{Na}_{2} \mathrm{SO}_{4}$ the number of starch inclusions was decreased in amyloplasts of columella cells, and the population composition of the plastids was changed in cells of the peripheral part of the cap; amyloplast statoliths were not detected, and cells contained proplastids that did not contain or contained little starch grains, as in plastids characteristic of meristematic tissues.

It is known that plastids of different areas of the cap can contain several types of inclusions - starch, protein globules (bodies), different crystals and plastoglobules (Kiss and Sack, 1989). Meristematic cells of the cap initials have plastids with single starch grains. Cells of columella contain starch-rich plastids (amyloplasts), which contain two types of starch inclusions: in the form of storage inclusions and performing the functions of statoliths. Amyloplast statoliths contain small starch grains. When the direction of the axis of the root changes, statoliths under the action of gravity move to a new area of the cytoplasm. Statoliths are considered as a gravity sensing structures. In contrast to ordinary starch grains, the statoliths are almost not consumed by the plant for metabolic processes. Amyloplast statoliths differ in structure from amyloplasts storing starch: in statoliths, the starch granules have a boundary layer $0.1-0.3 \mu \mathrm{m}$ thick. This boundary layer binds all the starch granules to a joint structural system inside the amyloplast (Staehelin et al., 2000). Also, proteinoplasts, which are plastids containing protein inclusions, are found in root cells of tobacco (Vigil and Ruddat, 1985). In the study of Hodson and Mayer (1987) it was demonstrated that the anatomy and ultrastructure of the root tip of cultivated isolated pea roots changed after 24-hour exposure to $120 \mathrm{mM} \mathrm{NaCl}$. In the cells of the apical zone of root the degradation of mitochondria and increased vacuolation were observed. Furthermore, the grouping of amyloplasts around the cell nuclei was noted. Authors suggested that salinity can affect the gravitropic reactions of root (Hodson and Mayer, 1987). When studying the effect of $\mathrm{NaCl}$ and $\mathrm{Na}_{2} \mathrm{SO}_{4}$ on the transformation of the cytoskeleton of the alfalfa root cells we found a significant change in the shape of the roots. They had significant bends and often formed a spiral structure at increased concentrations (Lazareva et al., 2017). However, at the applied concentration no such reaction was observed in the roots of tobacco. However, displacement of the statoliths towards the nucleus under the action of $\mathrm{NaCl}$, and a significant decrease in the starch content under the action of $\mathrm{Na}_{2} \mathrm{SO}_{4}$ were observed, with an increase in the salt concentration. Changes in the shape and fine organisation of plastids upon salinisation are a reversible adaptive response that is consistent with the observations made in other studies on barley (Xi, 1995).

Differences in the structural organisation of mitochondria and cytoplasm in cells of all tissues of the cap (Fig. 3) in the salinization treatment suggest that the differentiation of cells in the presence of $\mathrm{NaCl}$ and $\mathrm{Na}_{2} \mathrm{SO}_{4}$ is significantly delayed. It can be assumed that the death of cells of the cap and the release of metabolites into the external environment with respect to the tip of the root will also be delayed, which can be explained by the decrease in the activity of microorganisms associated with plant roots during salinisation (Lareen et al., 2016). The "younger" state of the cytoplasm and mitochondria of the cap cells probably facilitates the active maintenance of the metabolic and energy processes provided by the mitochondria under the action of salts (Fig. 3e, i), unlike to the "older" mitochondria in the columella cells and the peripheral zone of the cap of control plants (Fig. 3b, c).

In addition to gravitropism, hydrotropism also occurs in plants, in which the growing tip of the root performs a sensory role (Ponce et al., 2008). To implement hydrotropism, plants must overcome the dominant influence of gravitropism. It was shown that a moisture gradient or water stress caused the rapid degradation of statoliths and a decrease in starch content in the columella cells of Arabidopsis thaliana 
and radish (Raphanus sativus). In this case, the roots stimulated to hydrotropism showed a reduced gravitropic response. The authors of the study concluded that the weakening of the gravitropic response is associated with a loss of statoliths, which occurs in response to an increase in the moisture gradient or water stress (Takahashi et al., 2003). The degradation of amyloplasts in columella cells with a hydrotropic response occurs by autophagy (Nakayama et al., 2012), which is known to primarily focus on the survival of cells, but is also one of the mechanisms triggering a variant of programmed cell death (Üstün et al., 2017).

\section{CONCLUSIONS}

The most significant effect on plastids of the root cap in plants treated with equal isoosmotic concentrations was observed under sulfate salinization. Changes affected the plastids, mitochondria, and vacuoles of all studied tissues of the root cap. Plastids and mitochondria of the cells of the peripheral part of the cap underwent the most noticeable changes during salinisation. It was found that isoosmotic concentrations of $\mathrm{NaCl}$ and $\mathrm{Na}_{2} \mathrm{SO}_{4}$ caused a change in the amount of starch grains in the plastids of collumella cells and peripheral cells: decrease in the $\mathrm{NaCl}$ treatment and disappearance in the $\mathrm{Na}_{2} \mathrm{SO}_{4}$ treatment. This effect might be caused both by the action of different anions in the composition of the salts, and due to the difference in the concentration of sodium ions. We found that the statocytes of the root cap of the tobacco and their organelles were highly sensitive to the action of salts. It was shown that the structure of plastids in the cells of this zone under salinity was characterised by delay of development and a disturbance of starch accumulation. This observation can be useful in the development of simplified assessment tests for sensitivity to the action of salts.

Our data demonstrate the importance of structural analysis of plant cells and tissues before biochemical and physiological studies, which are based on evaluation of total amounts of various parameters and do not take into account the number, condition, ratio and size of cells of various tissues. In the future we plan to extend our studies to include also biochemical and physiological methods.

\section{ACKNOWLEDGEMENTS}

The work is conducted for the assignment AAAA-A17117090540061-4 from the Ministry of Science and Higher Education of the Russian Federation.

\section{REFERENCES}

Acosta-Motos, J. R., Ortuño, M. F., Bernal-Vicente, A., Diaz-Vivancos, P., Sanchez-Blanco, M. J., Hernandez, J. A. (2017). Plant responses to salt stress: Adaptive mechanisms. Agronomy, 7 (1), 18.

Ahmed, I. M., Cao, F., Han, Y., Nadira, U. A., Zhang, G., Wu, F. (2013). Differential changes in grain ultrastructure, amylase, protein and amino acid profiles between Tibetan wild and cultivated barleys under drought and salinity alone and combined stress. Food Chem., 141 (3), 2743-2750.
Andronis, E. A., Roubelakis-Angelakis K. A. (2010). Short-term salinity stress in tobacco plants leads to the onset of animal-like PCD hallmarks in planta in contrast to long-term stress. Planta, 231 (2), 437-448.

Baranova, E. N., Gulevich, A. A., Polyakov, V. Y. (2007). Effect of NaCl, $\mathrm{Na}_{2} \mathrm{SO}_{4}$, and mannitol on utilization of storage starch and formation of plastids in the cotyledons and roots of alfalfa seedlings. Russ. J. Plant Physiol., 54 (1), 59-67.

Baranova, E. N., Gulevich, A. A., Lavrova, N.V. (2009). [Баранова Г. Н., Гулевич А. А., Лаврова Н. В. Цитоплазматическая характеристика устойчивости мобилизации запасных веществ при прорастании семян томата в условиях засоления среды]. Izvestia of Timiryazev Agricultural Academy [Известия Тимирязевской сельскохозяйственной академии], № 3, 61-64 (in Russian).

Baranova, E. N., Gulevich, A. A., Maysuryan, A.N., Lavrova, N.V (2011). [Баранова, Е. Н., Гулевич, А. А., Майсурян, А. Н., Лаврова, Н. В. Изменения в субклеточных компартментах клеток семядолей табака в период прорастания при солевом и осмотическом воздействии]. Izvestia of Timiryazev Agricultural Academy [Известия Тимирязевской сельскохозяйственной академии], № 2, 69-74 (in Russian).

Bresler, E., McNeal, B. L., Carter, D. L. (2012). Saline and Sodic Soils: Principles-dynamics-modeling. Springer Science and Business Media, Berlin. 237 pp.

Chen, Z., Tang, W. (2017). Molecular mechanisms regulating storage root formation in plants. Int. J. Environ. Agr. Res., 3 (1), 93-103.

Čiamporová, M., Mistrík, I. (1993). The ultrastructural response of root cells to stressful conditions. Environ. Exp. Bot., 33, 11-26.

Dessaux, Y., Grandclément, C., Faure, D. (2016). Engineering the rhizosphere. Trends Plant Sci., 21 (3), 266-278.

Fanello, D. D., Bartoli, C. G., Guiamet, J. J. (2017). Qualitative and quantitative modifications of root mitochondria during senescence of above-ground parts of Arabidopis thaliana. Plant Sci., 258, 112-121.

Ghosh, D., Xu, J. (2014). Abiotic stress responses in plant roots: A proteomics perspective. Front. Plant Sci., 5 (6), 1-13.

Gill, S. S., Tuteja, N. (2010). Reactive oxygen species and antioxidant machinery in abiotic stress tolerance in crop plants. Plant Physiol. Biochem., 48 (12), 909-930.

Hamamoto, L., Hawes, M. C., Rost, T. L. (2006). The production and release of living root cap border cells is a function of root apical meristem type in dicotyledonous angiosperm plants. Annals Bot., 97 (5), 917-923.

Hetherington, A. J., Dubrovsky, J. G., Dolan, L. (2016). Unique cellular organization in the oldest root meristem. Curr. Biol., 26 (12), 1629-1633.

Hodson, M. J., Mayer, A. M. (1987). Salt-induced changes in the distribution of amyloplasts in the root cap of excised pea roots in culture. Ann. Bot., 59 (5), 499-503.

Ibrahim, W., Ahmed, I. M., Chen, X., Wu, F. (2017). Genotype-dependent alleviation effects of exogenous GSH on salinity stress in cotton is related to improvement in chlorophyll content, photosynthetic performance, and leaf/root ultrastructure. Environ. Sci. Poll. Res., 24 (10), 9417-9427.

Kamiya, M., Higashio, S. Y., Isomoto, A., Kim, J. M., Seki, M., Miyashima, S., Nakajima, K. (2016). Control of root cap maturation and cell detachment by BEARSKIN transcription factors in Arabidopsis. Development, 143 (21), 4063-4072.

Kiss, J.Z., Sack, F. D. (1989). Reduced gravitropic sensitivity in roots of a starch-deficient mutant of Nicotiana sylvestris. Planta, 180 (1), 123-130.

Lareen, A., Burton, F., Schäfer, P. (2016.) Plant root-microbe communication in shaping root microbiomes. Plant Mol. Biol., 90 (6). 575-587.

Lazareva, E. M., Baranova, E. N., Smirnova, E. A. (2017). Reorganization of interphase microtubules in root cells of Medicago sativa L. during acclimation to osmotic and salt stress. Cell Tissue Biol., 11 (4), 324-334.

Mitsuya, S., Takeoka, Y., Miyake, H. (2000). Effects of sodium chloride on foliar ultrastructure of sweet potato (Ipomoea batatas Lam.) plantlets 
grown under light and dark conditions in vitro. J. Plant Physiol., 157 (6), 661-667.

Nakayama, N. Smith, R. S., Mandel, T., Robinson, S., Kimura, S., Boudaoud, A., Kuhlemeier, C. (2012). Mechanical regulation of auxinmediated growth. Curr. Biol., 22 (16), 1468-1476.

Poljakoff-Mayber, A., Gale, J. (1975). Morphological and anatomical changes in plants as a response to salinity stress. Plants in Saline Environments. Springer, Berlin, Heidelberg, pp. 97-117.

Ponce, G., Rasgado, F. A., Cassab, G. I. (2008). Roles of amyloplasts and water deficit in root tropisms. Plant Cell Environ., 31 (2), 205-217.

Redmann, R. E. (1974). Osmotic and specific ion effects on the germination of alfalfa. Can. J. Bot., 52, 803-808.

Sam, O., Ramírez, C., Coronado, M. J., Testillano, P. S., Risueńo, M. D. C. (2003). Changes in tomato leaves induced by $\mathrm{NaCl}$ stress: Leaf organization and cell ultrastructure. Biol. Plantarum, 47 (3), 361.

Staehelin, L. A. Zheng, H. Q., Yoder, T. L., Smith, J. D., Todd, P. (2007). Columella cells revisited: Novel structures, novel properties, and a novel gravisensing model. Grav. Space Res., 13 (2), 95-100.

Su, S. H., Gibbs, N. M., Jancewicz, A. L., Masson, P. H. (2017). Molecular mechanisms of root gravitropism. Curr. Biol., 27 (17), 964-972.
Takahashi, N. Yamazaki, Y., Kobayashi, A., Higashitani, A., Takahashi, H. (2003). Hydrotropism interacts with gravitropism by degrading amyloplasts in seedling roots of Arabidopsis and radish. Plant Physiol., 132 (2), 805-810.

Thalmann, M., Santelia, D. (2017). Starch as a determinant of plant fitness under abiotic stress. New Phytol., 214 (3), 943-951.

Usatov, A. V., Lutsenko, E. K., Fedorenko, A. G., Fedorenko, G. M. (2014). Cell ultrastructure of root meristem of wheat under conditions of chloride salinization [Усатов, А. В. Луценко, Э. К., Федоренко, А. Г., Федоренко, Г. М. Ультраструктура клеток корневой меристемы пшеницы в условиях хлоридного засоления]. Eurasian Union of Scientists [Евразийский союз ученьих], 6, 103-106 (in Russian).

Üstün, S., Hafren, A., Hofius, D. (2017). Autophagy as a mediator of life and death in plants. Curr. Opin. Plant Biol., 40, 122-130.

Vigil, E. L., Ruddat, M. (1985). Development and enzyme activity of protein bodies in proteinoplasts of tobacco root cells. Histochemistry, 83 (1), $17-27$.

Xi, Y. X. (1995). NaCl-induced amoeboid plastids and mitochondria in meristematic cells of barley roots. Biol. Plantarum, 37 (3), 363-380.

Zheng, H. Q., Staehelin, L. A. (2001). Nodal endoplasmic reticulum, a specialized form of endoplasmic reticulum found in gravity-sensing root tip columella cells. Plant Physiol., 125 (1), 252-265.

Received 25 July 2018

Accepted in the final form 15 November 2018

\section{ORGANOIIDU ULTRASTRUKTURĀLĀS IZMAIN̦AS TABAKAS SAKN̦U UZMAVU ŠŪNĀS SĀLS IETEKMĒ}

Parādīts, ka $\mathrm{NaCl}$ un $\mathrm{Na}_{2} \mathrm{O}_{4}$ ietekmē notiek atškirīgas organoīdu izmainas dažādās saknu uzmavu zonās. 